\title{
Population history of northern Vietnamese inferred from nonmetric cranial trait variation
}

\author{
Tsunehiko HANIHARA ${ }^{1}$, Hirofumi MatsumurA ${ }^{2}$, Yoshinori KAWAKUBO ${ }^{3}$, NGUYen Lan Coung ${ }^{4}$, \\ NGUYEN Kim Thuy ${ }^{4}$, Marc F. OXENHAM ${ }^{5}$, Yukio DODO ${ }^{6 *}$ \\ ${ }^{1}$ Department of Anatomy, Kitasato University School of Medicine, Sagamihara 252-0374, Japan \\ ${ }^{2}$ Department of Anatomy, Sapporo Medical University, Sapporo 060-8556, Japan \\ ${ }^{3}$ Department of Anatomy and Biological Anthropology, Saga Medical School, Saga 849-8501, Japan \\ ${ }^{4}$ The Vietnamese Institute of Archaeology, Hanoi, Vietnam \\ ${ }^{5}$ School of Archaeology and Anthropology, Australian National University, Canberra ACT 0200, Australia \\ ${ }^{6}$ Department of Anatomy and Anthropology, Tohoku University School of Medicine, Sendai 980-8575, Japan
}

Received 9 September 2011; accepted 24 October 2011

\begin{abstract}
In this study, nine nonmetric cranial traits were recorded for ancient human remains excavated at early prehistoric (the late Pleistocene, early Holocene, and Pre-Pottery Neolithic) and late prehistoric (the Neolithic and early Iron age) archeological sites in northern Vietnam. The comparative samples consist of prehistoric and early historic crania from the lower Yangtze River basin, together with recent cranial series from Vietnam, Thailand, South China, and Australia. The results, based mainly on the measure of divergence, are as follows: (1) the early prehistoric northern Vietnam group is distinct from the subsequent inhabitants of northern Vietnam and neighboring populations; (2) the cranial series of northern Vietnam and the surrounding region from the late prehistoric to recent times through early historic period exhibit relative homogeneity, suggesting population continuity; (3) the recent Han Chinese from southern China, one of the possible representatives of East Asians, are relatively distant from all groups from the prehistoric age onwards; and (4) a clear separation of Aboriginal Australians from all the comparative samples, including the early prehistoric northern Vietnamese, is evident. These findings suggest partial support for the two opposing hypotheses, i.e. the two-layer model and the regional-continuity model, for the population history of Southeast Asians, at least, in the northern Vietnamese region. This may be further compatible with the recent hypothesis for modern human dispersals: an earlier out-of-Africa expansion of Australians than other contemporary Eurasians including Southeast Asians.
\end{abstract}

Key words: two-layer model, regional-continuity model, prehistoric northern Vietnam, East/Southeast Asia, Australia

\section{Introduction}

With respect to the peopling of Southeast Asia, early researchers frequently described morphological features akin to Australian Aborigines or Melanesians for a majority of the skeletal remains recovered from the pre-ceramic period, despite the fragmentary nature of remains and the lack of a clear chronological framework (e.g. Evans, 1918; Duckworth, 1934; Mijsberg, 1940; Trevor and Brothwell, 1962; Jacob, 1967). These early observations fostered the hypothesis that Southeast Asia was initially colonized at least 50000 years ago (the first layer) by anatomically modern humans (sometimes referred to as AustraloMelanesians), who later exchanged genetic material with

* Correspondence to: Yukio Dodo, Department of Anatomy and Anthropology, Tohoku University School of Medicine, 2-1 Seiryocho, Aoba-ku, Sendai 980-8575, Japan.

E-mail: dodo@med.tohoku.ac.jp

Published online 9 February 2012

in J-STAGE (www.jstage.jst.go.jp) DOI: 10.1537/ase.110909 new immigrants (the second layer) from East Asia (the region mainly corresponding to present China), leading the formation of present-day Southeast Asians (Callenfels, 1936; Mijsberg, 1940; von Koenigswald, 1952; Coon, 1962; Jacob, 1967, 1975; Brace et al., 1991). This hypothesis, known as the two-layer model, has now received some support from more recent and extensive studies base on new skeletal discoveries (Matsumura and Zuraina, 1999; Matsumura and Hudson, 2005; Matsumura and Pookajorn, 2005; Matsumura, 2006, 2011a, b; Bulbeck et al., 2007; Matsumura et al., 2008a, b). These recent researches, which refine the context of two-layer model, clearly demonstrate that the late Pleistocene and early Holocene colonists of Southeast Asia, represented by Hoabinhian foragers, were descendants of the first occupants of late Pleistocene Sundaland, who shared ancestors with present-day Australian Aboriginal and Melanesian populations, but never with majority of present-day Southeast Asians.

Despite the long history of the two-layer hypothesis, a number of scholars have critiqued it. A major controversial hypothesis is the regional-continuity or local-evolution 
model that declares modern Southeast Asians to be the result of long-standing genetic continuity without any significant influx of gene flow from outside the region. This scenario is, for instance, supported by 'Sundadont/Sinodont' dental studies (Turner, 1989, 1990, 1992), and multivariate cranial metric analyses by Hanihara $(1994,2006)$ and Pietrusewsky (2006, 2008, 2010). Further, this hypothesis has received support from genetic research, suggesting that Southeast Asia was a major geographic source of East Asian populations, within which the origins of all inhabitants of Southeast and East Asia were derived from a single primary source colonizing the region (e.g. Capelli et al., 2001; The HUGO Pan-Asian SNP Consortium, 2009).

On the other hand, the two-layer hypothesis has been supported by historical, linguistic, and archeological data, in which the expansions of the language families represented by Austronesian and Austroasiatic, for instance, were driven in association with the dispersal of rice-farming peoples during the Neolithic and early Metal (Bronze and Iron) ages (Higham, 1998, 2001; Bellwood and Renfrew, 2003; Diamond and Bellwood, 2003; Bellwood, 2005; Sagart, 2008). Both linguistic and archeological data suggest that southern China and Taiwan were the ultimate sources of these language and food production dispersals, with archeological evidence for the origins of Neolithic farming societies in the Yangtze basin during the early Holocene (Bellwood, 2005; Lu, 2006).

Bioanthropological evidence, supporting the agriculturally driven demographic expansion from southern China some time during the Neolithic, has come from recent excavations in mainland Southeast Asia, the most representative being from the Man Bac, a 3600-4000-year-old Neolithic cemetery site in northern Vietnam. In terms of local cultural chronologies, the material culture of Man Bac, located on the southern edge of the Red River delta, displays many similarities with the Phung Nguyen culture (4000-3500 years BP), which generally showed evidence for rice cultivation and flourished along the upper reaches of the Red River Delta (Hiep and Phung, 2004). One of the most important skeletal findings at Man Bac is the demonstration of significant morphological discontinuity with the Hoabinhian and mid Holocene pre-Neolithic pottery using cultures (PNPC), represented by the Da But series (see Oxenham and Matsumura, 2011), that exhibit Australo-Melanesian features with respect to quantitative (metric) craniodental morphology (Matsumura et al., 2008b, 2011a; Matsumura, 2011a, b). The close affinity of the majority of Man Bac individuals with later Iron Age Dong Son and Chinese Neolithic samples from the Yangtze River region suggests that the Neolithic was the turning point in terms of the microevolutionary history of this region. The skeletal sequence at Man Bac, demonstrating an initial appearance of immigrants in northern Vietnam, clearly illustrates the two-layer model in the context of local and regional populations in debates over the demographic expansion associated with the spread of agriculture.

In order to further test and/or refine this model of major population change in Vietnam in terms of a range of comparative approaches to skeletal morphology, the present study analyzed the qualitative (nonmetric) cranial morphology of the Man Bac sample. Cranial nonmetric traits have been widely accepted to be effective for reconstructing population histories, not only within limited geographic regions but also globally (Dodo and Ishida, 1990; Ossenberg, 1994; Dodo and Kawakubo, 2002; Hanihara et al., 2003; Dodo and Sawada, 2010). The occurrences of cranial nonmetric traits were compared between the temporally disparate skeletal sequences discussed above for the Hoabinhian, Pre-Pottery Neolithic (PPNC, essentially Da But series), Neolithic Man Bac, and Metal period assemblages available for study in northern Vietnam, to test the validity of two-layer hypothesis as a model for understanding the population history of Southeast Asia.

\section{Materials and Methods}

The prehistoric series from northern Vietnam used in the present study are given in Table 1 . The early prehistoric northern Vietnamese (EPNV) samples comprise the late Pleistocene Son Vi, early Holocene Hoabinhian and Bac Son, and Pre-Pottery Neolithic Culture (PPNC) Da But cranial series, totaling 67 individuals. The late prehistoric northern Vietnamese (LPNV) series includes the Neolithic Man Bac and the early Iron Age samples from Dong Son, totaling 73 individuals.

The present study is concerned with nonmetric cranial variation. The prehistoric series listed in Table 1 were examined by Y.D.

The prehistoric and early historic comparative samples consist of cranial series from the Weidun site and those from several sites attributed to the Eastern Zhou and the Western Han periods located in the lower reaches of the Yangtze River. The two early Yangtze series were reported by Wakebe (2002). The Weidun site is considered to belong to the early

Table 1. Cranial series of prehistoric northern Vietnam

\begin{tabular}{|c|c|c|c|c|}
\hline Culture & Site & Date (years BP) & No. of crania & Collection \\
\hline \multicolumn{5}{|c|}{ Early Prehistoric Northern Vietnamese (EPNV) } \\
\hline Son Vi & Mai Da Dieu & $20000-12000$ & 1 & Institute of Archaeology, Hanoi \\
\hline Hoabinhian & Hang Chou, Mai Da Nuoc, Mai Da Dieu, Dong Can & $15000-8000$ & 4 & Institute of Archaeology, Hanoi \\
\hline Bac Son & Lang Cuom, Pho Binh Gia, Cau Giat & $10000-6000$ & 18 & Musée de l'Homme, Paris \\
\hline Da But & Con Co Ngua & $6000-5000$ & 44 & Institute of Archaeology, Hanoi \\
\hline \multicolumn{5}{|c|}{ Late Prehistoric Northern Vietnamese (LPNV) } \\
\hline Phung Nguyen & Man Bac & $4000-3600$ & 33 & Institute of Archaeology, Hanoi \\
\hline Dong Son & Minh Duc, Vinh Quang, Quy Chu, Nui Nap & $3000-1700$ & 40 & Institute of Archaeology, Hanoi \\
\hline
\end{tabular}


rice-cultivating (7000-5200 years BP) Majiabang Culture (Zou and $\mathrm{Li}, 2002$ ). Skeletal remains excavated from the Weidun site are, however, assigned to c. 5000 years BP (Chen and Huang, 1995).

In addition to the prehistoric and early historic samples described above, this study includes four recent cranial series from Vietnam, Thailand, South China, and Australia. With the exception of the Thai sample examined by Y.D., all data were recorded by T.H. Relevant summary information on the nature of the samples is given in Table 2 .

In the present study the following nine nonmetric traits, for which more than 20 sides of crania were observable in the prehistoric northern Vietnamese sample, were used because these traits are commonly used by other observers and have relatively low inter-observer errors (Ishida and Dodo, 1990): metopism (MET); supraorbital foramen (SOF); ossicle at lambda (OL); parietal notch bone (PNB); hypoglossal canal bridging (HGCB); ovale-spinosum open (OSO); medial palatine canal (MPC); transverse zygomatic suture vestige (TZS); and mylohyoid groove bridging (MHB). The scoring procedures for each trait are described in Dodo (1974) and Dodo and Ishida (1990). All the traits used were dichotomized into categories of present or absent.

In this study, sexes were pooled and separate records and counts were kept for the bilateral traits in order to maximize the sample size even when only one side was observable. Fisher's exact probability test was used to identify the significance of differences in trait occurence between the samples compared. Tests were conducted using the software package HALBAU-5 for Windows (Gendaisugakusha).

The biological distance between every pair of samples was defined as follows:

$$
\begin{aligned}
& \text { Measure of divergence (MD) } \\
& =\sum_{j=1}^{r}\left[\left(\theta_{1 j}-\theta_{2 j}\right)^{2} /\left(1 / 4 n_{1 j}+1 / 4 n_{2 j}\right)\right]
\end{aligned}
$$

where $\theta=\sin ^{-1} \sqrt{p}$ in radian, $n$ is the sample size, and $r$ is the number of traits. When frequencies are zero, we performed Bartlett's adjustment, replacing a zero proportion by $1 / 4 n$ (Snedecor and Cochran, 1980). This formula was originally developed by Fisher (1949) for testing the sexual dimorphism in recombination fraction of allelic locus of house mice. Yamaguchi (1967) applied the measure of divergence (MD) to estimate biological distance based on the frequencies of nonmetric cranial traits.

It is well known that Smith's mean measure of divergence (MMD) provides one of the best estimates of biological divergence among samples for nonmetric morphological traits (Sjøvold, 1977). In the case of small sample size, however, the MMD distance, or a corrected MMD, which is calculated by subtracting the variance of the differences $\left(1 / n_{1 j}+1 / n_{2 j}\right)$ from the raw one, often yields a negative value. In the present study, some negative values of MMDs were obtained. On the other hand, the advantage of the use of MD includes: (1) negative values are not calculated; and (2) a test of significance can be performed since they distribute as a $\chi^{2}$-statistic with $r$ degrees of freedom (Rao, 1952). Moreover, Pearson's correlation coefficients between distance coefficients of MMDs and MDs based on 25 population
Table 2. Brief information of the recent cranial series used for comparison*

\begin{tabular}{ll} 
Sample name & \multicolumn{1}{c}{ Brief information } \\
\hline Vietnam & $\begin{array}{l}\text { Hanoi, Da Nang, and other cities (Musée de } \\
\text { l'Homme, Paris) }\end{array}$ \\
Anailand & $\begin{array}{l}\text { Anatomical collection housed in Siriraji Hospital, } \\
\text { Mahidol University mainly from Bangkok }\end{array}$ \\
Shath China & $\begin{array}{l}\text { Shanghai, Canton, Hong Kong, and other cities from } \\
\text { southern China: Han Chinese from South of Cheng }\end{array}$ \\
& $\begin{array}{l}\text { Yangtze River (Natural History Museum, London; } \\
\text { Musée de l'Homme, Paris; American Museum of }\end{array}$ \\
Natural History, New York) \\
Mainly from coastal regions of New South Wales \\
(Australian Museum, Sydney; Natural History \\
Museum, London; Cambridge University, Cam- \\
bridge; American Museum of Natural History, New \\
York; National Museum of Natural History, Wash- \\
ington DC; Musée de l'Homme, Paris)
\end{tabular}

* For references, see Ishida and Dodo (1997) and Hanihara and Ishida (2001a, b, c, d).

samples (300 pairs of samples in total) are 0.936 . This suggests the usefulness of MD for estimating similarities/dissimilarities among samples with relatively small sample sizes.

To visualize the patterning of intergroup relationships, principal coordinate (PCO) analysis developed by Gower (1966) was applied to the obtained MD matrix. Calculations for MD and PCO were processed using a N88-BASIC program coded by Y.D. and Tanaka et al. (1984), respectively. These N88-BASIC programs were modified for a Windows system using BASIC/98 ver. 5 (Dennougumi).

\section{Results}

The frequencies of nine nonmetric cranial traits and number of individuals or sides scored for the early and late prehistoric northern Vietnamese samples together with the six comparative series are provided in Table 3. The metopism occurs much less in the Australian cranial series. The ossicle at lambda, ovale-spinosum open, and mylohyoid groove bridging are not observable in the early prehistoric northern Vietnamese sample. The early prehistoric northern Vietnamese and Australian samples have lower frequencies of the supraorbital foramen than six other samples. The parietal notch bone is observed with relatively high frequency in the late prehistoric northern Vietnamese, Zhou/Han, and southern Chinese samples. The frequencies of the hypoglossal canal bridging are relatively high in the early prehistoric northern Vietnamese and Zhou/Han cranial series. The frequencies of the transverse zygomatic suture vestige are generally low in all the cranial samples examined here as compared to those in many of the Northeast Asian groups (Ishida, 1995).

Table 4 presents the results of tests for the difference in trait frequencies between the early and late prehistoric northern Vietnamese samples. The Fisher's exact probability test emphasizes the observation that the frequency of the supraorbital foramen in the late prehistoric northern Vietnamese sample is significantly higher than in the early prehistoric northern Vietnamese sample $(P<0.01)$. 
Table 3. Comparison of side-incidences of nonmetric traits among the eight cranial series from Vietnam, South China, Thailand, and Australia

\begin{tabular}{|c|c|c|c|c|c|c|c|c|c|c|c|c|c|c|c|c|}
\hline \multirow{2}{*}{ Trait } & \multicolumn{2}{|c|}{ EPNV } & \multicolumn{2}{|c|}{ LPNV } & \multicolumn{2}{|c|}{ Weidun $^{1}$} & \multicolumn{2}{|c|}{ Zhou/Han ${ }^{1}$} & \multicolumn{2}{|c|}{ Vietnam } & \multicolumn{2}{|c|}{ Thailand } & \multicolumn{2}{|c|}{ South China } & \multicolumn{2}{|c|}{ Australia } \\
\hline & $n$ & $P$ & $n$ & $P$ & $n$ & $P$ & $n$ & $P$ & $n$ & $P$ & $n$ & $P$ & $n$ & $P$ & $n$ & $P$ \\
\hline MET & 59 & 0.051 & 65 & 0.062 & 38 & 0.053 & 32 & 0.031 & 36 & 0.056 & 131 & 0.023 & 100 & 0.090 & 182 & 0.005 \\
\hline $\mathrm{SOF}$ & 99 & 0.192 & 100 & 0.370 & 69 & 0.406 & 52 & 0.519 & 72 & 0.306 & 262 & 0.424 & 198 & 0.404 & 358 & 0.120 \\
\hline $\mathrm{OL}$ & 40 & $0.006^{*}$ & 52 & 0.058 & 22 & 0.045 & 23 & 0.217 & 36 & 0.111 & 119 & 0.092 & 93 & 0.247 & 138 & 0.174 \\
\hline PNB & 31 & 0.097 & 76 & 0.184 & 43 & 0.070 & 42 & 0.214 & 70 & 0.157 & 250 & 0.116 & 184 & 0.299 & 266 & 0.117 \\
\hline HGCB & 38 & 0.132 & 73 & 0.082 & 45 & 0.044 & 44 & 0.136 & 70 & 0.043 & 260 & 0.077 & 190 & 0.068 & 332 & 0.048 \\
\hline OSO & 29 & $0.009^{*}$ & 65 & 0.046 & 44 & 0.023 & 46 & 0.022 & 72 & 0.042 & 262 & 0.019 & 184 & 0.033 & 272 & 0.033 \\
\hline MPC & 51 & 0.020 & 95 & 0.021 & 74 & 0.041 & 50 & 0.060 & 70 & 0.071 & 262 & 0.027 & 196 & 0.041 & 340 & 0.038 \\
\hline TZS & 43 & 0.023 & 65 & 0.015 & 37 & 0.081 & 42 & $0.006 *$ & 62 & $0.004 *$ & 250 & 0.048 & 184 & 0.049 & 266 & 0.015 \\
\hline МHB & 51 & $0.005^{*}$ & 105 & 0.048 & 81 & 0.099 & 44 & 0.023 & 46 & 0.087 & 236 & 0.047 & 92 & 0.054 & 232 & 0.103 \\
\hline
\end{tabular}

${ }^{1}$ Wakebe (2002); * Zero proportion is counted as $1 / 4 n$ (Bartlett's adjustment).

Table 4. Fisher's exact probability test for the difference in trait frequencies between the early prehistoric northern Vietnamese (EPNV) and late prehistoric northern Vietnamese (LPNV)

\begin{tabular}{lcrrrrrrr}
\hline \multirow{2}{*}{ Trait } & \multicolumn{3}{c}{ EPNV } & & \multicolumn{3}{c}{ LPNV } & \multirow{2}{*}{$P$} \\
\cline { 2 - 4 } \cline { 6 - 7 } & $n$ & + & \multicolumn{1}{c}{$\%$} & & \multicolumn{1}{c}{$n$} & + & $\%$ & \\
\hline MET & 59 & 3 & 5.1 & & 65 & 4 & 6.2 & 1.0000 \\
SOF & 99 & 19 & 19.2 & & 100 & 37 & 37.0 & 0.0071 \\
OL & 40 & 0 & 0.0 & & 52 & 3 & 5.8 & 0.2547 \\
PNB & 31 & 3 & 9.7 & & 76 & 14 & 18.4 & 0.3842 \\
HGCB & 38 & 5 & 13.2 & & 73 & 6 & 8.2 & 0.5062 \\
OSO & 29 & 0 & 0.0 & & 65 & 3 & 4.6 & 0.5500 \\
MPC & 51 & 1 & 2.0 & & 95 & 2 & 2.1 & 1.0000 \\
TZS & 43 & 1 & 2.3 & & 65 & 1 & 1.5 & 1.0000 \\
MHB & 51 & 0 & 0.0 & & 105 & 5 & 4.8 & 0.1734 \\
\hline
\end{tabular}

The results of MD statistic applied to the nine nonmetric cranial traits for the eight samples are set out in Table 5. Interpopulation relationships between the early and late prehistoric northern Vietnamese samples and the recent Vietnamese sample, based on the distance matrix shown in Table 5, are illustrated in Figure 1. The distances between the early prehistoric northern Vietnamese sample and the late prehistoric northern Vietnamese as well as the recent Vietnamese sample are significant $(P<0.05)$. On the other hand, dissimilarity between the late prehistoric northern Vietnamese and recent Vietnamese samples is statistically not significant. Such findings suggest that the early prehistoric northern Vietnamese sample is distinct from the subsequent inhabitants in this region.

Figure 2 is a two-dimensional expression resulting from PCO analysis of MD values among seven East/Southeast
Asian samples. The insignificant MD values between every pair of samples from late prehistoric northern Vietnamese, Weidun, recent Vietnamese, and recent Thai (Table 5) indicate that these groups form a relatively tight cluster. On the other hand, the clear separation of the early prehistoric northern Vietnamese sample from all other samples is indicated. These findings, together with the significant MD values between the early prehistoric northern Vietnamese sample and other samples as shown in Table 5, suggests that the early prehistoric northern Vietnamese group appears to be an outlier relative to the late prehistoric and the subsequent inhabitants in Vietnam.

The MD value between the Zhou/Han and Weidun samples is statistically significant. However, the MD values between the Zhou/Han sample and the late prehistoric northern Vietnamese, recent Vietnamese, Thai, and South Chinese series are not statistically significant. In Figure 2, the Zhou/ Han sample is situated at an intermediate position between the late prehistoric northern Vietnamese and recent South Chinese samples. The recent South Chinese are the most peripherally positioned sample, separating from the late prehistoric northern Vietnamese, Weidun, and recent Vietnamese series. Except for the Zhou/Han sample, the distance measured by MD between the recent South Chinese and all other samples is statistically significant.

It is often emphasized that the late Pleistocene and early Holocene inhabitants of Southeast Asia were ancestral to modern Australian and Melanesian lineages (Bellwood, 1997; Matsumura et al., 2001; Matsumura, 2006). Taking such a hypothesis into account, the PCO analysis was applied to the MD matrix shown in Table 5, including the Australian sample. Figure 3 shows the first two principal

Table 5. MD matrix among the eight cranial series from Vietnam and the surrounding regions

\begin{tabular}{|c|c|c|c|c|c|c|c|c|}
\hline & EPNV & LPNV & Weidun & Zhou/Han & Vietnam & Thailand & S China & Australia \\
\hline EPNV & & 16.98 & 22.46 & 31.04 & 20.29 & 31.90 & 51.77 & 38.56 \\
\hline LPNV & 16.98 & & 9.79 & 10.93 & 6.45 & 8.73 & 18.14 & 47.22 \\
\hline Weidun & 22.46 & 9.79 & & 18.31 & 10.19 & 6.63 & 23.04 & 37.87 \\
\hline Zhou/Han & 31.04 & 10.93 & 18.31 & & 13.24 & 12.76 & 11.21 & 50.13 \\
\hline Vietnam & 20.29 & 6.45 & 10.19 & 13.24 & & 15.72 & 18.89 & 20.29 \\
\hline Thailand & 31.90 & 8.73 & 6.63 & 12.76 & 15.72 & & 39.19 & 96.44 \\
\hline South China & 51.77 & 18.14 & 23.04 & 11.21 & 18.89 & 39.19 & & 103.62 \\
\hline Australia & 38.56 & 47.22 & 37.87 & 50.13 & 20.29 & 96.44 & 103.62 & \\
\hline
\end{tabular}

Italic indicates $P>0.05$. 


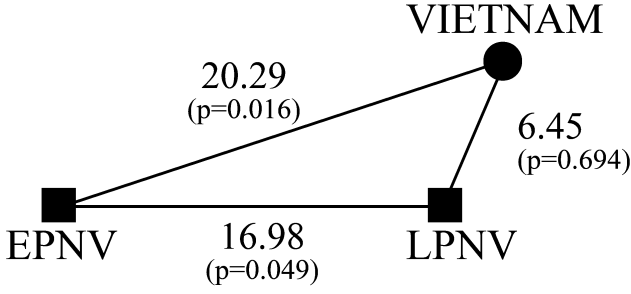

Figure 1. Triangle indicating the MDs among the early prehistoric northern Vietnamese (EPNV), late prehistoric northern Vietnamese (LPNV), and recent Vietnamese. Closed squares, prehistoric; closed circle, recent.

coordinates, accounting for $77.4 \%$ of the total variance. The early prehistoric northern Vietnamese sample is slightly closer to the Australian sample than the late prehistoric northern Vietnamese sample. However, a clear separation between the Australian and the early prehistoric northern Vietnamese samples is evident. The MD value between the two samples is significant at the $1 \%$ level. These findings suggest that the early prehistoric inhabitants in northern Vietnam, c. 12000-5000 years BP, do not necessarily share the same lineage leading to present-day Australians as far as cranial nonmetric characteristics are concerned.

\section{Discussion}

The degree to which morphological characteristics reflect population history or adaptive changes in subsistence behaviors, including environmental factors, has been the focus of much heated debate (Roseman, 2004; Betti et al., 2009; Hubbe et al., 2009; Relethford, 2010). Ossenberg (1994) and Hanihara et al. (2003) demonstrated that nonmetric cranial variation, when considered as a whole, varies across regions and periods in a manner matching neutral expectations. Such findings may allow us to fruitfully discuss a plausible population history for northern Vietnam.

The issue of the origin and movement of Southeast Asians
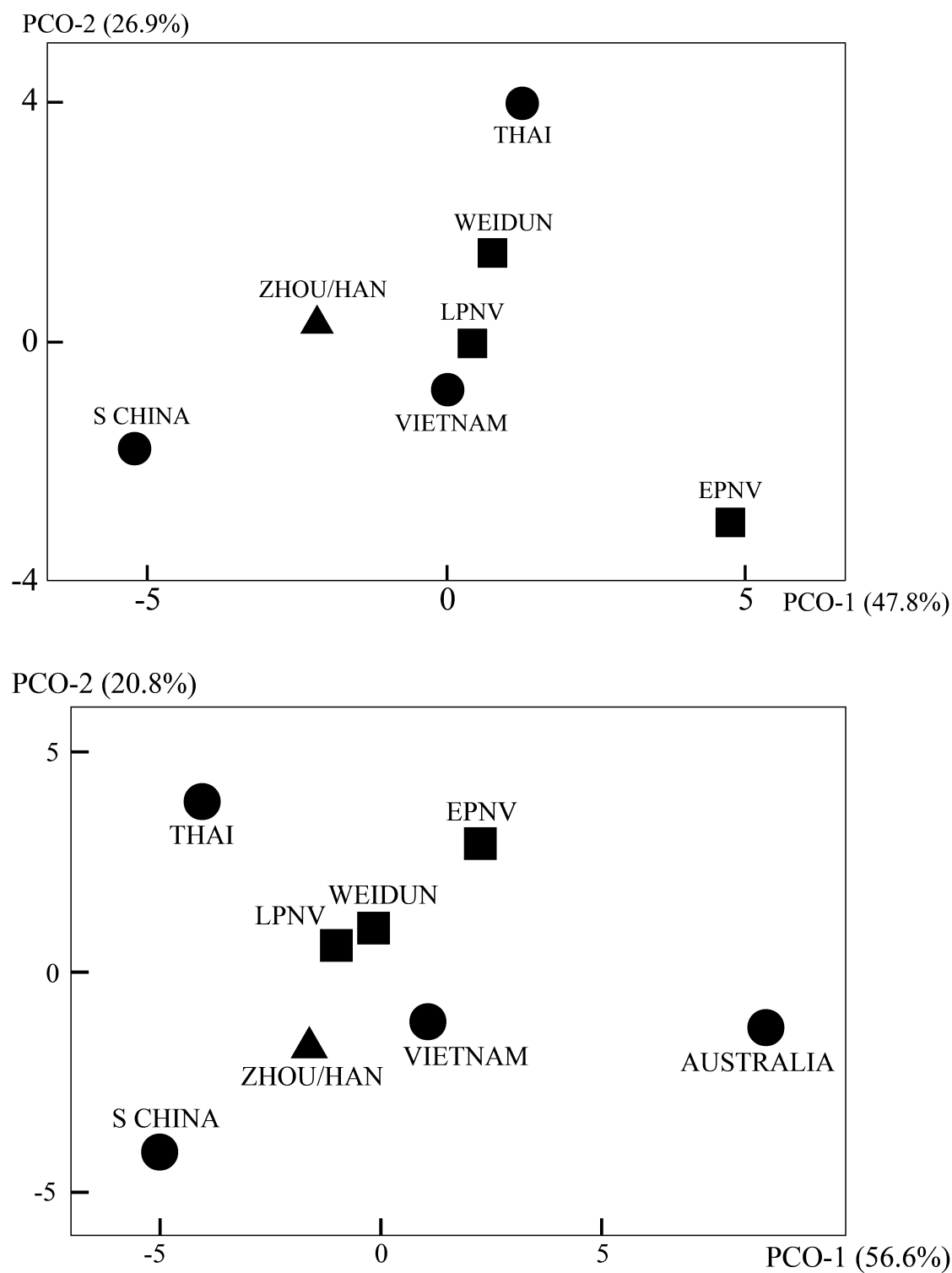

Figure 2. The 1st and 2nd principal coordinates based on the MD matrix among the seven cranial series from Vietnam and the neighboring regions. Closed squares, prehistoric; closed triangle, early historic; closed circles, recent; EPNV, early prehistoric northern Vietnamese; LPNV, late prehistoric northern Vietnamese.
Figure 3. The 1st and 2nd principal coordinates based on the MD matrix among the eight cranial series from Vietnam, South China, Thailand, and Australia. Closed squares, prehistoric; closed triangle, early historic; closed circles, recent; EPNV, early prehistoric northern Vietnamese; LPNV, late prehistoric northern Vietnamese. 
has been one of the most controversial areas in archeology and anthropology for many years (e.g. Turner, 1990; Bellwood, 1997; Shi et al., 2005; The HUGO Pan-Asian SNP Consortium, 2009). The recent fossil record and archeological analyses ostensibly favor a complete or nearly complete replacement model (Bellwood, 1997; Matsumura et al., 2001, 2008a, b, 2011a, b; Matsumura and Hudson, 2005; Matsumura, 2006, 2011a, b). This model, the two-layer and replacement model, assumes that the indigenous inhabitants of Southeast Asia trace their phenotypic and genetic ancestry to an Australian-like lineage. Subsequently, a wave of migrants from somewhere in what is now southern China displaced and absorbed the majority of indigenous populations at some point around 5000-4000 years BP (Matsumura, 2006, 2011a, b; Matsumura et al., 2011a, b; Oxenham and Matsumura, 2011).

Here we discuss the extent to which such a general and global Southeast Asian population history model is applicable to northern Vietnam. In this context we examine the twolayer model by dividing it into two hypothesis: (1) the indigenous inhabitants of northern Vietnam were displaced by the expansion of more northerly distributed populations as a result of demographic growth related to agricultural development from around the middle Holocene; and (2) the aboriginal populations in the area of northern Vietnam represent the ancestral lineages that eventually led to present-day Australians.

Regarding the first hypothesis, a close affinity between the late prehistoric northern Vietnamese and recent Vietnamese, together with the distinctiveness of early prehistoric northern Vietnamese, as shown in Figure 1 and Figure 2, appears to fit the two-layer model emphasized by Matsumura (2006, 2011a, b) and Matsumura et al. (2008a, b, 2011a, b). The result shown in Figure 2, moreover, suggests that migrants from an outside source, for example Weidun and Zhou/Han populations from the lower Yangtze, had a strong influence on the pattern of morphological variation of the late prehistoric and subsequent northern Vietnamese.

Figure 2 and Figure 3 show the distinctiveness of the southern Chinese (one of the representatives of a major East Asian population-recent Han Chinese) from Southeast Asians. This finding may be inconsistent with the recent hypothesis for the Southeast Asian origin of East/Northeast Asians mainly supported by genetic studies (Shi et al., 2005; The HUGO Pan-Asian SNP Consortium, 2009). Future discussions of the prehistoric peopling of eastern Asia should deal with the issue of the dissimilarity of Southeast Asians and East/Northeast Asians.

Figure 3 shows what happens when the Australian sample is added to a series of Southeast Asian groups. While the interpopulation relationships shown in Figure 2 are retained for the most part, the early indigenous inhabitants of northern Vietnam, c. 12000-5000 years BP, do not necessarily share morphological characteristics with the recent Australian population. This indicates that the early Holocene inhabitants of the northern Vietnamese region were not the lineages leading to the present-day Australians, negating the second hypothesis of the model.

In contrast to the two-layer or replacement model, the regional-continuity or local-evolution model, in which present Southeast Asians have evolved in Southeast Asia from earlier late Pleistocene peoples adapted to the tropical rainforest, rather than experiencing significant gene flow into Southeast Asia from an outside source (mainly southern China), is espoused by several scholars (Bulbeck, 1982; Turner, 1990; Hanihara, 1994, 2006; Pietrusewsky, 2006, 2008, 2010; Lertrit et al., 2008). The results shown in Figure 3 and Table 5 may support the local-evolution hypothesis at least in the region of northern Vietnam during and after the mid-Holocene periods.

These findings lead us to propose a modified version of the two-layer model as well as local-evolution model for the formation of present-day Southeast Asian physical characteristics, as far as northern Vietnam is concerned at least. How can the nonmetric cranial traits of the early prehistoric northern Vietnamese be interpreted and explained in a modern human evolutionary context?

Recent genetic and morphological studies indicate that an important factor behind the unique physical makeup of contemporary Southeast Asians may be attributed more or less to multiple gene flows from the west in the distant past (Lahr, 1996; Underhill et al., 2001; Hanihara, 2006). In other words, the Australian lineages may have been descendants of an earlier human dispersal into Southeast Asia, populations which may not have contributed to the rise of late Pleistocene and the subsequent Southeast Asians (Rasmussen et al., 2011). Another possible explanation may be a scenario of a morphological differentiation of modern humans in and after the terminal Pleistocene (Brown, 1996; Harvati, 2009; Hubbe et al., 2011). Harvati (2009) and Hubbe et al. (2011) suggest that the geographic differentiation of modern human morphology, including modernization and gracilization, is a relatively late phenomenon that occurred after the initial settlement of major geographic regions of the world. However, it still remains to be determined whether or not such morphological differentiation in fact occurred in vast areas of Southeast Asia including northern Vietnam. A higher mutation or drift rate, based mainly on small population size, may be also an undeniable possibility (Relethford, 1996; Powell and Neves, 1999). Since the present study only examined the relationship between the prehistoric northern Vietnamese and neighboring populations with relatively small sample sizes, such speculations are tentative and preliminary.

The results of the present study do not provide a clear choice between the two-layer hypothesis and local-evolution hypothesis for the formation of present-day Southeast Asian physical characteristics. As Lahr (1996) emphasizes, information on a greater temporal and spatial scale is essential for understanding the process of differentiation not only on a worldwide scale but also regional or local scales.

\section{Acknowledgments}

For their kind permission to study the materials under their care, we express our sincere thanks to Tong T. Tin, Nguyen G. Hai, Nguyen K. Dung, and Nguyen T.M. Huong of Institute of Archaeology, Hanoi; P. Mennecier, F. Demeter, A. Langaney, and M.A. Pereira da Silva of Musée de l'Homme, Paris; S. Sangvichien of Siriraj Hospital, 
Mahidol University, Bangkok; T. Molleson, R. Kruszynski, L.T. Humphrey, and C. Stringer of the Natural History Museum, London; R. Foley, M.M. Lahr, and M. Bellatti of the University of Cambridge; D. Hunt, D. Oswley, S. Ousley, R. Potts, M. London, and D.H. Ubelaker of the National Museum of Natural History, Smithonian Institution, Washington, DC; I. Tattersall, K. Mowbray, and G. Sawyer of the American Museum of Natural History, New York; J. Spechit, P. Gordon, L. Bonshek, and N. Goodsell of the Australian Museum, Sydney; J. Stone and D. Donlon of the University of Sydney; and D. Henley of the New South Wales Aboriginal Land Council, Sydney. This study was supported by a Grant-in-Aid in 2003-2005 (No. 15405018), 2008-2010 (No. 20370096), and 2009-2011 (No. 21405014) from the Japan Society for the Promotion of Science, the Toyota Foundation 2006-2007 (No. D06-R-0035), and an Australian Research Council Grant (DP 0774 079).

\section{References}

Bellwood P. (1997) Prehistory of the Indo-Malaysian Archipelago, revised edition. University of Hawaii Press, Honolulu.

Bellwood P. (2005) Examining the farming/language dispersal hypothesis in the East Asian context. In: Sagart L., Blench R., and Sanchez-Mazas A. (eds.), The Peopling of East Asia: Putting Together Archaeology, Linguistics and Genetics. Routledge, London, pp. 17-30.

Bellwood P. and Renfrew C. (2003) Examining the Farming/Language Dispersal Hypothesis. McDonald Institute for Archaeological Research, Cambridge.

Betti L., Balloux F., Amos W., Hanihara T., and Manica A. (2009) Distance from Africa, not climate, explains within-population phenotypic diversity in humans. Proceedings of Royal Society B, 276: 809-814.

Brace C.L., Tracer D.P., and Hunt K.D. (1991) Human craniofacial form and the evidence for the peopling of the Pacific. Bulletin of the Indo-Pacific Prehistory Association, 12: 247269.

Brown P. (1996) The first modern East Asians: another look at Upper Cave 101, Liujiang and Minatogawa 1. In: Omoto K. (ed.), Interdisciplinary Perspectives on the Origins of the Japanese. International Research Center for Japanese Studies, Kyoto, pp. 105-124.

Bulbeck D. (1982) A re-evaluation of possible evolutionary processes in Southeast Asia since the late Pleistocene. Bulletin of the Indo-Pacific Prehistory Association, 3: 1-21.

Bulbeck D., Oxenham M., Nguyen L.C., and Nguyen K.T. (2007) Implication of the terminal Pleistocene skull from Hang Muoi, northern Vietnam. Khao Co Hoc (Vietnamese Archaeology), 2-2007: 42-52.

Callenfels V.S. (1936) The Melanesoid civilizations of eastern Asia. Bulletin of the Raffles Museum, 1 (Series B): 41-51.

Capelli C., Wilson J.F., Richards M., Stumpf M.P.H., Gratrix F., Oppenheimer S., Underhill P., Pascali V.L., Ko T.M., and Goldstein D.B. (2001) A predominantly indigenous paternal heritage for the Austronesian-speaking peoples of insular Southeast Asia and Oceania. American Journal of Human Genetics, 68: 432-443.

Chen W. and Huang X. (1995) Provenance of the human skeletal materials. In: Yamaguchi B. and Huang X. (eds.), Studies on the Human Skeletal Remains from Jiangnan, China. National Science Museum Monographs No. 10, National Science Museum, Tokyo, p. 1.

Coon C.S. (1962) The Origin of Races. Alfred A. Knopf, New York.

Diamond J. and Bellwood P. (2003) Farmers and their languages: the first expansions. Science, 300: 597-603.
Dodo Y. (1974) Non-metrical cranial traits in the Hokkaido Ainu and the northern Japanese of recent times. Journal of the Anthropological Society of Nippon, 82: 31-51.

Dodo Y. and Ishida H. (1990) Population history of Japan as viewed from cranial nonmetric variation. Journal of the Anthropological Society of Nippon, 98: 269-287.

Dodo Y. and Kawakubo Y. (2002) Cranial affinities of the EpiJomon inhabitants in Hokkaido, Japan. Anthropological Science, 110: $1-32$

Dodo Y. and Sawada J. (2010) Supraorbital foramen and hypoglossal canal bridging revisited: their worldwide frequency distribution. Anthropological Science, 118: 65-71.

Duckworth W.L.H. (1934) Human remains from rock-shelters and caves in Perak, Pahang and Perlis and from Selinsing. Journal of Malayan Branch of the Royal Asiatic Society, 12: 149167.

Evans I.H.N. (1918) Preliminary report on cave exploration near Lenggong, upper Perak. Journal of the Federated Malay States Museum, 7: 227-234.

Fisher R.A. (1949) A preliminary linkage test with agouti and undulated mice. Heredity, 3: 229-241.

Gower J.C. (1966) Some distance properties of latent root and vector methods used in multivariate analysis. Biometrika, 53: $325-338$.

Hanihara T. (1994) Craniofacial continuity and discontinuity of Far Easterners in the late Pleistocene and Holocene. Journal of Human Evolution, 27: 417-441.

Hanihara T. (2006) Interpretation of craniofacial variation and diversification of East and Southeast Asians. In: Oxenham M. and Tayles N. (eds.), Bioarchaeology of Southeast Asia. Cambridge University Press, Cambridge, pp. 91-111.

Hanihara T. and Ishida H. (2001a) Frequency variations of discrete cranial traits in major human populations. I. Supernumerary ossicle variations. Journal of Anatomy, 198: 689-706.

Hanihara T. and Ishida H. (2001b) Frequency variations of discrete cranial traits in major human populations. II. Hypostotic variations. Journal of Anatomy, 198: 707-725.

Hanihara T. and Ishida H. (2001c) Frequency variations of discrete cranial traits in major human populations. III. Hyperostotic variations. Journal of Anatomy, 199: 251-272.

Hanihara T. and Ishida H. (2001d) Frequency variations of discrete cranial traits in major human populations. IV. Vessel and nerve related variations. Journal of Anatomy, 199: 273-287.

Hanihara T., Ishida H., and Dodo Y. (2003) Characterization of biological diversity through analysis of discrete cranial traits. American Journal of Physical Anthropology, 121: 241-251.

Harvati K. (2009) Into Eurasia: a geometric morphometric reassessment of the Upper Cave (Zhoukoudian) specimens. Journal of Human Evolution, 57: 751-762.

Hiep T.H. and Phung H.V. (2004) Man Bac location and its relationship through ceramic data. Khao Co Hoc (Vietnamese Archaeology), 6-2004: 13-48 (in Vietnamese with English summary).

Higham C.F.W. (1998) Archaeology, linguistics and the expansion of the East and Southeast Asian Neolithic. In: Blench R. and Spriggs M. (eds.), Archaeology and Language II: Archaeological Data and Linguistic Hypotheses. Routledge, London, pp. $103-114$

Higham C.F.W. (2001) Prehistory, language and human biology: is there a consensus in East and Southeast Asia? In: Jin L., Seielstad M., and Xiao C.J. (eds.), Genetic, Linguistic and Archaeological Perspectives on Human Diversity in Southeast Asia. World Scientific, Singapore, pp. 3-16.

Hubbe M., Hanihara T., and Harvati K. (2009) Climate signatures in the morphological differentiation of worldwide modern human populations. Anatomical Record, 292: 1720-1733.

Hubbe M., Harvati K., and Neves W. (2011) Paleoamerican morphology in the context of European and East Asian late Pleistocene variation: implications for human dispersion into the New World. American Journal of Physical Anthropology, 
144: 442-453.

HUGO Pan-Asian SNP Consortium, The (2009) Mapping human genetic diversity in Asia. Science, 326: 1541-1545.

Ishida H. (1995) Nonmetric cranial variation of Northeast Asians and their population affinities. Anthropological Science, 103: 385-401.

Ishida H. and Dodo Y. (1990) Interobserver error in scoring nonmetric cranial traits. Journal of the Anthropological Society of Nippon, 98: 403-409.

Ishida H. and Dodo Y. (1997) Cranial variation in prehistoric human skeletal remains from the Marianas. American Journal of Physical Anthropology, 104: 399-410.

Jacob T. (1967) Some Problems Pertaining to the Racial History of the Indonesian Region. Ph.D. Dissertation, University of Utrecht.

Jacob T. (1975) Morphology and paleontology of early man in Java. In: Tuttle R.H. (ed.), Paleoanthropology, Morphology, and Paleoecology. Mouton, The Hague, pp. 311-324.

Lahr M.M. (1996) The Evolution of Modern Human Diversity. Cambridge University Press, Cambridge.

Lertrit P., Poolsuwan S., Thosarat R., Sanpachudayan T., Boonyarit H., Chinpaisal C., and Suktitipat B. (2008) Genetic history of Southeast Asian populations as revealed by ancient and modern human mitochondrial DNA analysis. American Journal of Physical Anthropology, 137: 425-440.

Lu T.L.D. (2006) The occurrence of cereal cultivation in China. Asian Perspectives, 45: 129-158.

Matsumura H. (2006) The population history of Southeast Asia viewed from morphometric analyses of human skeletal and dental remains. In: Oxenham M. and Tayles N. (eds.), Bioarchaeology of Southeast Asia. Cambridge University Press, Cambridge, pp. 33-58.

Matsumura H. (2011a) Quantitative cranio-morphology at Man Bac. In: Oxenham M.F., Matsumura H., and Nguyen K.D. (eds.), Man Bac: the Excavation of a Neolithic Site in Northern Vietnam, the Biology. Terra Australis 33, Australian National University E-Press, Canberra, pp. 21-31.

Matsumura H. (2011b) Quantitative and qualitative dentalmorphology at Man Bac. In: Oxenham M.F., Matsumura H., and Nguyen K.D. (eds.), Man Bac: the Excavation of a Neolithic Site in Northern Vietnam, the Biology. Terra Australis 33, Australian National University E-Press, Canberra, pp. 43-63.

Matsumura H. and Hudson M.J. (2005) Dental perspectives on the population history of Southeast Asia. American Journal of Physical Anthropology, 127: 182-209.

Matsumura H. and Pookajorn S. (2005) Morphometric analysis of the Late Pleistocene human remains from Moh Khiew Cave in Thailand. Journal of Comparative Human Biology Homo, 56: $93-118$.

Matsumura H. and Zuraina M. (1999) Metric analyses of the early Holocene human skeleton from Gua Gunung Runtuh in Malaysia. American Journal of Physical Anthropology, 109: 327-340.

Matsumura H., Cuong N.L., Thuy N.K., and Anezaki T. (2001) Dental morphology of the early Hoabinhian, the Neolithic Da But and the Metal Age Dong Son cultural peoples in Vietnam. Zeitschrift für Morphologie und Anthropologie, 83: 59-73.

Matsumura H., Yoneda M., Dodo Y., Oxehham M.F., Cuong N.L., Thuy N.K., Dung L.M., Long V.T., Yamagata M., Sawada J., Shinoda K., and Takigawa W. (2008a) Terminal Pleistocene human skeleton from Hang Cho Cave, northern Vietnam: implications for the biological affinities of Hoabinhian people. Anthropological Science, 116: 201-217.

Matsumura H., Oxenham M.F., Dodo Y., Domett K., Thuy N.K., Cuong N.L., Dong N.K., Huffer D., and Yamagata M. (2008b) Morphometric affinity of the late Neolithic human remains from Man Bac, Ninh Binh Province, Vietnam: key skeletons with which to debate the 'two layer' hypothesis.
Anthropological Science, 116: 135-148.

Matsumura H., Oxenham M.F., Thuy N.K., Cuong N.L., and Dung N.K. (2011a) Population history of mainland Southeast Asia: the two layer model in the context of northern Vietnam. In: Enfield N. and White J. (eds.), Dynamics of Human Diversity: the Case of Mainland Southeast Asia. Pacific Linguistics, Canberra, pp. 153-178.

Matsumura H., Domett K.M., and O'Reilly D.J.W. (2011b) On the origin of pre-Angkorian peoples: perspectives from cranial and dental affinity of the human remains from Iron Age Phum Snay, Cambodia. Anthropological Science, 119: 67-79.

Mijsberg W.A. (1940) On a Neolithic Paleo-Melanesian lower jaw found in kitchen midden at Guar Kepah, Province Wellesley, Straits Settlements. Proceedings of 3rd Congress of Prehistorians of the Far East, Singapore, pp. 100-118.

Ossenberg N.S. (1994) Origins and affinities of the native people of northwestern North America: the evidence of cranial nonmetric traits. In: Bonichsen R. and Steele D.G. (eds.), Method and Theory for Investigating the Peopling of Americas. Center for the First Americans, Oregon State University, Corvallis, Oregon, pp. 79-115.

Oxenham M.F. and Matsumura H. (2011) Man Bac: regional, cultural and temporal context. In: Oxenham M.F., Matsumura H., and Nguyen K.D. (eds.), Man Bac: the Excavation of a Neolithic Site in Northern Vietnam, the Biology. Terra Australis 33, Australian National University E-Press, Canberra, pp. 127-133.

Pietrusewsky M. (2006) A multivariate craniometric study of the prehistoric and modern inhabitants of Southeast Asia, East Asia and surrounding regions: a human kaleidoscope? In: Oxenham M. and Tayles N. (eds.), Bioarchaeology of Southeast Asia. Cambridge University Press, Cambridge, pp. 5990.

Pietrusewsky M. (2008) Craniometric variation in Southeast Asia and neighboring regions: a multivariate analysis of cranial measurements. Human Evolution, 23: 49-86.

Pietrusewsky M. (2010) A multivariate analysis of measurements recorded in early and more modern crania from East Asia and Southeast Asia. Quaternary International, 211: 42-54.

Powell J.F. and Neves W.A. (1999) Craniofacial morphology of the first Americans: pattern and process in the peopling of the New World. Yearbook of Physical Anthropology, 42: 153188.

Rao C.R. (1952) Advanced Statistical Methods in Biometric Research. Wiley, New York.

Rasmussen M., Guo X., Wang Y., Lohmueller K.E., Rasmussen S., Albrechtsen A., Skotte L., Lindgreen S., Metspalu M., Jombart T., Kivisild T., Zhai W., Eriksson A., Manica A., Orlando L., Vega F.D.L., Tridico S., Metspalu E., Nielsen K., Ávila-Arcos M.C., Moreno-Mayar J.V., Muller C., Dortch J., Gilbert M.T.P., Lund O., Wesolowska A., Karmin M., Weinert L.A., Wang B., Li J., Tai S., Xiao F., Hanihara T., van Driem G., Jha A.R., Ricaut F-X. de Knijff P., Migliano A.B., Gallego-Romero I., Kristiansen K., Lambert D.M, Brunak S., Forster P., Brinkmann B., Nehlich O., Bunce M., Richards M., Gupta R., Bustamante C.D., Krogh A., Foley R.A., Lahr M.M., Balloux F., Sicheritz-Pontén T., Villems R., Nielsen R., Jun W., and Willerslev E. (2011) An Aboriginal Australian genome reveals separate human dispersals into Asia. Science, 334: 94-98.

Relethford J.H. (1996) Genetic drift can obscure population history: problem and solution. Human Biology, 68: 29-44.

Relethford J.H. (2010) Population-specific deviations of global human craniometric variation of a neutral model. American Journal of Physical Anthropology, 142: 105-111.

Roseman C.C. (2004) Detecting interregionally diversifying natural selection on modern human cranial form by using matched molecular and morphometric data. Proceedings of National Academy of Science, USA, 101: 12824-12829.

Sagart L. (2008) The expansion of setaria farmers in East Asia: a 
linguistic and archaeological model. In: Sanchez-Mazas A., Blench R., Ross M., Peiros I., and Lin M. (eds.), Past Human Migrations in East Asia: Matching Archaeology, Linguistics and Genetics. Routledge, London, pp. 133-157.

Shi H., Dong Y., Wen B., Xiao C., Underhill P.A., Shen P., Chakraborty R., Li J., and Su B. (2005) Y-chromosome evidence of southern origin of the East Asian-specific haplogroup O3-M112. American Journal of Human Genetics, 77: 408-419.

Sjøvold T. (1977) Non-metrical divergence between skeletal populations: the theoretical foundation and biological importance of C.A.B. Smith's Mean Measure of Divergence. Ossa, 4 (Supplement 1): 1-133.

Snedecor G.W. and Cochran W.G. (1980) Statistical Methods. The Iowa State University Press, Iowa.

Tanaka Y., Tarumi T., and Wakimoto K. (1984) Handbook for Statistical Analysis by Personal Computer, II Multivariate Analysis. Kyoritu-Shuppan, Tokyo (in Japanese).

Trevor J.C. and Brothwell D.R. (1962) The human remains of Mesolithic and Neolithic date from Gua Cha, Kelantan. Federation Museums Journal, 7: 6-22.

Turner C.G., II. (1989) Teeth and prehistory in Asia. Scientific American, 260: 70-77.

Turner C.G., II. (1990) Major features of sundadonty and sinodonty, including suggestions about East Asian microevolution, population history, and late Pleistocene relationships with Australian Aboriginals. American Journal of Physical
Anthropology, 82: 295-317.

Turner C.G., II. (1992) Microevolution of East Asian and European populations: a dental perspective. In: Akazawa T., Aoki K., and Kimura T. (eds.), The Evolution and Dispersal of Modern Humans in Asia. Hokusensha, Tokyo, pp. 415-438.

Underhill P.A., Passarino G., Lin A.A., Shen P., Lahr M.M., Foley R.A., Oefner P.J., and Cavalli-Sforza L.L. (2001) The phylogeography of Y chromosome binary haplotypes and the origins of modern human populations. Annals of Human Genetics, 65: 43-62.

von Koenigswald G.H.R. (1952) Evidence of a prehistoric Australo-Melanesoid population in Malaya and Indonesia Southwestern Journal of Anthropology, 8: 92-96.

Wakebe T. (2002) Human skeletal remains excavated from Jiangnan area in China as viewed from cranial nonmetric variation. In: Nakahashi T. and Li M. (eds.), Ancient People in the Jiangnan Region, China. Kyushu University Press, Fukuoka, pp. 35-49.

Yamaguchi B. (1967) A Comparative Osteological Study of the Ainu and the Australian Aborigines. Australian Institute of Aboriginal Studies, Occasional Papers No. 10, Canberra.

Zou H. and Li M. (2002) Brief discussion on the historical and cultural background of human bones in the south of the lower reaches of the Yangtze River. In: Nakahashi T. and Li M. (eds.), Ancient People in the Jiangnan Region, China. Kyushu University Press, Fukuoka, pp. 3-15. 